http://jmscr.igmpublication.org/home/ ISSN (e)-2347-176x ISSN (p) 2455-0450 crossref DOI: https://dx.doi.org/10.18535/jmscr/v8i1.06

Journal Of Medical Science And Clinical Research

\title{
Levels and Correlates of Self-reported Maternal Morbidity in Women in a Community outreach area of a Teaching Hospital in Bihar
}

Authors

\author{
Dr Manasij Mitra ${ }^{1}$, Dr Gautam Sarker ${ }^{2}$, Dr Maitraye Basu ${ }^{3 *}$
}

${ }^{1}$ Associate Professor, Department of Anesthesiology, MGM Medical College and LSK Hospital, Kishanganj

${ }^{2}$ Professor, Department of Anesthesiology, MGM Medical College and LSK Hospital, Kishanganj

${ }^{3}$ Clinical Tutor, Department of Biochemistry, MGM Medical College and LSK Hospital, Kishanganj

*Corresponding Author

Dr Maitraye Basu

\begin{abstract}
Background: Globally, maternal mortality ratio (MMR) dropped from 385 maternal deaths per 100,000 live births in 1990 to 216 in 2015, a 44\% reduction. Despite substantial progress, maternal mortality still remains a matter of great public health importance. Maternal mortality indicates only the tip of the iceberg. For each woman who dies as the direct or indirect result of pregnancy, many more women experience life-threatening complications. Consistent with the higher rates of maternal mortality in LMICs, maternal morbidity rates are also higher in LMICs than HICs.

Objectives: The objectives of the study was to estimate the levels and correlates of self-reported maternal morbidity. The data was entered in Microsoft Excel and exported and analyzed in SPSS (v19.0). Descriptive statistics, bivariate and multivariate analysis were used to arrive at the conclusions in the study.

Methodology: This was a cross-sectional study on Maternal Morbidity using self reports without clinical examinations among women living in the community being served by MGM Medical College and LSK Hospital, Kishanganj, Bihar. The sample size of the study was calculated as 200 considering the prevalence of maternal morbidity in the state and after considering the possibility of nonresponse to the study.

Results: The prevalence of antenatal morbidity was found to be $23.5 \%$, morbidity during labor was $16.5 \%$ while post partum morbidity was $25.5 \%$. The overall maternal morbidity was $44.5 \%$. Religion, occupation, past history of ailments, decision taking obtaining healthcare, access to pocket money, type of past delivery, type of last delivery, wantedness of the index pregnancy, food intake during the antenatal period, physical activity during the antenatal period and awareness of danger signs of pregnancy came out as significant correlates of maternal morbidity in the bivariate analysis. Finally food intake and physical activity during the antenatal period, awareness of danger signs of pregnancy and type of last delivery came out as significant correlates of maternal morbidity in the multivariate analysis.

Conclusion: It is evident from the findings of the study that the causes of maternal morbidity are deeply entrenched in the sociocultural milieu. The findings bring out the socio-economic context in which the women suffer from maternal morbidity and stresses on the importance of self-reported community based studies on maternal morbidity to understand the social determinants of maternal morbidity more and thus come up with plausible solutions.

Keywords: Maternal morbidity; Women's autonomy; Antenatal; Labor; Post partum; Correlates.
\end{abstract}




\section{Introduction}

Maternal mortality is a sentinel event used globally as a benchmark to monitor maternal health, the overall quality of reproductive health care, and the progress countries have made toward international development goals ${ }^{.1}$

Globally, maternal mortality ratio (MMR) dropped from 385 maternal deaths per 100,000 live births in 1990 to 216 in 2015, a 44\% reduction $^{2}$

Though most of the high income countries (HICs) as defined by the World Bank have consistently shown a decline in the Maternal Mortality Rates over the last 25 years, low and middle incomes countries (LMICs)* still bear $99 \%$ of the burden of maternal mortality. ${ }^{3}$ A Sustainable Development Goal for 2030 is to reduce the global MMR to 70 per 100,000 live births and for no country to exceed two times that ratio (140 per 100,000 live births). ${ }^{4}$

Despite substantial progress, maternal mortality still remains a matter of great public health importance. Maternal mortality indicates only the tip of the iceberg. For each woman who dies as the direct or indirect result of pregnancy, many more women experience life-threatening complications. ${ }^{5,6}$ Consistent with the higher rates of maternal mortality in LMICs, maternal morbidity rates are also higher in LMICs than HICs. ${ }^{7}$

The International Classification of Diseases (ICD10) defines maternal death as "[The] death of a woman while pregnant or within 42 days of the end of pregnancy, irrespective of the duration and site of the pregnancy, from any cause related to or aggravated by the pregnancy or its management, but not from accidental or incidental causes" 8

India has made great strides in maternal health over the past several decades, reducing its maternal mortality ratio (MMR) from 556 to 174 maternal deaths per 100,000 live births between 1990 and 2015 (World Bank 2016a). With this progress, India came closer to achieving United Nations (UN) Millennium Development Target 5A, reducing its MMR by 75 percent by 2015
(World Bank 2016a; World Health Organization 2015).

This progress is largely attributed to the policies and initiatives to increase access to maternal health services. However, the rate of improvement has slowed down, with large disparities existing between states and across populations and the country continues to contribute almost one-quarter of maternal deaths globally. Added to this, India also accounts for a high but difficult to measure rate of so-called near-miss maternal deaths that often lead to maternal morbidity. ${ }^{9}$

Although the incidence of maternal morbidity in India is largely unknown due to the country's lack of diagnoses and under-reporting, it is estimated that millions of Indian women experience pregnancy-related morbidity. As part of the Global Burden of Disease estimates, India contributes to one-fifth of the disability-adjusted life years lost globally due to maternal health conditions (World Health Organization 2008). These suggest there is still progress to be made in maternal health in India. ${ }^{10}$

MMR is particularly high in India's northern states, where its poorest and most marginalized populations reside. At the same time, MMR in many wealthier states, where access to care is better, also remain above the country's goals; only Maharashtra and Kerala have an MMR below 70 (United Nations 2016) per 100,000 live births.

The state of Bihar registers a MMR of 208 . (Maternal mortality ratio by state, 2013. Ministry of Health and Family Welfare 2015c).

Information on maternal morbidity is frequently collected from hospital settings, which represent only a section who seeks healthcare. Communitybased studies are rare. Moreover, detailed knowledge on the levels of maternal mortality and morbidity and the causes of their occurrence does not exists. ${ }^{11}$

Thus a better understanding of maternal morbidity, will lead to a lesser burden with framing of better policies and implementation of tailored services. $^{12}$ 


\section{Materials and Methods}

This was a cross-sectional study on Maternal Morbidity using self-reports without clinical examinations among women living in the community being served by MGM Medical College and LSK Hospital, Kishanganj, Bihar.

The sample size of the study was calculated as 200 considering the prevalence of maternal mortality in the state and after considering the possibility of nonresponse to the study.

The selected criteria included women in the age group 15-49 years who delivered a live birth or a still birth or in whom the pregnancy terminated in abortion (spontaneous/induced) in the last 1 year from $1^{\text {st }}$ June 2018 to $31^{\text {st }}$ May 2019 and who were willing to participate. Study subjects were selected at random from the sample frame which included 356 women.

Ethical clearance was obtained from Institutional ethics committee.

The operational definition of maternal morbidity used in this study was adopted from the definition of maternal morbidity as coined by the Maternal Morbidity Working Group (MMWG) (WHO,2012) as "any health condition attributed to and/or aggravated by pregnancy and childbirth that has a negative impact on the woman's wellbeing". 13

The dependent variable in the study was maternal morbidity. As per the standard practice protocol where in uncomplicated institutional deliveries with mother and baby keeping fine and the discharge being planned within 48 hours, hospitalization $>2$ days and or blood transfusion or being bed ridden for $>24$ hours or affecting the normal day to day activities of the woman like going to the toilet, bathing, eating were set as the different parameters for measuring maternal morbidity.

The correlates of maternal morbidity were assessed through different independent variables like the socioeconomic status of the women, history of ailments prior to the last (index) pregnancy, the women's autonomy and decision making power measured by her ability to take decisions regarding obtaining healthcare and access to pocket money, pregnancy history prior to the last (index) pregnancy, pregnancy history of the last (index) pregnancy, antenatal profile during the last (index) pregnancy, the woman's healthcare seeking behavior and availability and quality of healthcare services.

SLI (Standard of Living Index) has been measured based on the NFHS-2 criteria with those with overall scores $0-14$ being considered as hailing from low SLI, 15-24 as medium SLI and 25-67 as High SLI.

Standard definitions of Spontaneous abortion, Induced abortion, Antenatal period, Labour and Postpartum period were used in the study. To include the cases of late maternal morbidity, complaints of the women extending beyond six weeks (42 days) after delivery or termination of pregnancy to one year were included.

Date collection was done by visit to individual homes of study subjects using a pretested semistructured questionnaire translated into the local dialect of Hindi.

The data was entered in Microsoft Excel and exported and analyzed in SPSS (v19.0). Descriptive statistics, bivariate and multivariate analysis were used to arrive at the conclusions in the study.

\section{Results}

\section{Demographic profile of the participants}

The Socio-economic profile of the study population is depicted in [Table 1]

Out of 200 women interviewed, $57.5 \%$ were Muslims and $42.5 \%$ Hindus. The study population belonging to the age group 15-19 years was $23.5 \%$, while $43.5 \%$ belonged to the age group 20-24 years, 25 percent belonged to the age group 25-29 years, $5.5 \%$ belonged to the age group 3034 years, 2 percent belonged to the age group 35 39 years and $0.5 \%$ belonged to the age group 40 44 years. There were no cases belonging to the age group 45-49 years. The mean age was 22.78 \pm 4.23 years. The range being 16 years to 42 years. The lowest age of first pregnancy among the cases 
was as low as 15 years to as high as 30 years with the mean age being $18.93 \pm 3.02$ years.

More than half of the study population $(50.5 \%)$ of the women did not have any formal education, while $24 \%$ had $1-5$ years of schooling, $23 \%$ had $6-$ 10 years of schooling, $1.5 \%$ had passed the $10+2$ level, and only 1 percent had completed graduation. Majority of the study population were housewives while those who were occupied were mostly employed as housemaids, teachers and vegetable sellers.

All the 200 women interviewed were married and 95.5\% were staying with their husbands while $2.5 \%$ had been deserted by their husbands. A very small proportion of the women (1\%) were separated and the remaining 1 percent had their husbands working outside. As far as the husband's education status was concerned, $38.3 \%$ had no formal education, $27.5 \%$ had $1-5$ years of schooling, $28.5 \%$ had 6-10 years of schooling, and $5.2 \%$ had passed $10+2$ level while only $0.5 \%$ had completed graduation.

Of the study population, $38 \%$ belonged to the low SLI, majority $(56.5 \%)$ belonged to medium SLI while only $5.5 \%$ belonged to the high SLI.

Of the study population, $85 \%$ had no history of ailments. $15 \%$ had past history of ailments like hypertension $(3 \%)$, anemia $(0.5 \%)$, TB $(3.5 \%)$, malaria $(2.5 \%)$, jaundice $(2.5 \%)$, asthma $(1.5 \%)$ and others like bloody diarrhea, rashes, worm infestation $(1.5 \%)$. Of those cases who had past history of ailments, $76.7 \%$ sought healthcare for these ailments.

\section{Women's Autonomy and Decision Making}

Women's autonomy and decision making has been described using their decision making with regard to obtaining healthcare, their vulnerability to domestic violence and their access to independent resources by way of pocket money. This has been depicted in Table 2. Of the study population, $34 \%$ took decisions themselves regarding obtaining healthcare, $2.5 \%$ took decisions themselves along with their husband while majority $(63.5 \%)$ of the women had no power themselves to take decisions regarding obtaining healthcare. The study population having access to pocket money was $53.5 \%$ while $45.5 \%$ had no access to pocket money. Out of 200 women interviewed, $28.5 \%$ women complained of being beaten or physically mistreated in the last one year while $3.5 \%$ were unwilling to answer this question. Out of the women who complained of being beaten or physically mistreated in the last 1 year, $77.2 \%$ complained of being beaten a few times in the last 1 year while the rest complained of being beaten multiple times in the last 1 year.

[Table 2]

\section{Women's Pregnancy History}

The women's pregnancy history was described in terms of the number of pregnancies experienced, the various outcomes of these pregnancies in terms of live births, still births and abortions, the type of delivery of the index pregnancy and type of attendance at delivery. [Table 3] depicts this.

\section{Pregnancy Related Care and Healthcare Seeking}

The profile and nature of care taken by women during pregnancy in terms of nature and quality of antenatal visits, the wantedness status of the index pregnancy, the nature of food intake during pregnancy (same as before, reduced/increased) and awareness of the danger signs for which caution has to be exercised have all been described in [Table 4]

\section{Morbidity Profile}

As per the study, maternal morbidity during the antenatal period was found as $23.5 \%$, during labour $16.5 \%$ and in the post partum period it was found to be $25.5 \%$. The overall morbidity (any woman experiencing antenatal morbidity or morbidity during labour or post partum morbidity considered as having maternal morbidity) was found to be $44.5 \%$.

This was low in comparison to studies done in other parts of India which could be due to the maternal healthcare services provided in this 
community through the Medical College. It could also be that as the levels of awareness and education were poor among the women in the community, the self reported maternal morbidity was low.

The major complaints in the antenatal period included mostly severe pain abdomen (11.5\%); severe vomiting (11.5\%); pallor, fatigability, tingling, dizziness (10.5\%); painful urination $(8 \%)$; swelling of legs, body and face $(8 \%)$; very high fever (6\%) and malaria (4\%).

The major complaints during labour included mostly prolonged labour> 18 hours (7\%); excessive bleeding per vagina requiring blood transfusion (6\%); severe pain abdomen (1.5\%); retained placenta (3\%); convulsions not from fever $(1 \%)$ and very high fever $(0.5 \%)$.

The major complaints during the post partum period included mostly wound pain (5.5\%); pallor, fatigability, tingling, dizziness $(5.5 \%)$; severe pain abdomen (10.5\%); pain during vaginal intercourse $(5 \%)$; painful urination $(7 \%)$; very high fever $(4.5 \%)$ and severe pain in the breast $(2.5 \%)$.

In this study $97.5 \%$ of the women sought antenatal care though awareness about the danger signs was very low $(14.5 \%)$ and $93.5 \%$ had institutional deliveries. This could be due to this community being served by the Medical College and also due to the constant touch of the women with the Medical College healthcare workers.

\section{Correlates of Maternal Morbidity}

Bivariate Analysis to find out associations between the outcome variable (maternal morbidity) and the other variables (determinants) and these are described in Table 1.

An association was found between religion and maternal morbidity ( $\mathrm{P}$ value=0.000). Muslim women were found to have more maternal morbidity (OR:3.99; 95\% CI 2.17-7.36). This could be due to the fact that majority of the Muslims hailed from low SLI families and were occupied which could have adversely affected their food intake and physical activity during the antenatal period and resulted in more maternal morbidity.

Maternal morbidity was associated with occupation of the woman $(\mathrm{P}$ value $=0.023)$. Women who were employed were found to be suffering more from maternal morbidity (OR: 3.63; 95\% CI 1.24-10.6). This could be due to the fact that women who were occupied also had to engage themselves in household activities which only increased the amount of their physical activity during the antenatal period.

Again there was an association between past history of ailments and maternal morbidity ( $\mathrm{P}$ value $=0.000$ ) with women reporting past history of ailments having more maternal morbidity (OR: 5.18; 95\% CI 2.10-12.74) than those without any past history of ailments. This is quite obvious from the fact that these women could have poor general health and so have more morbidity. It could also be that past ailments in these women gave rise to a better understanding of the danger signs of pregnancy (through prior contact with the health system) and so the perceived morbidity (self reported morbidity was higher in them).

Women's decision taking regarding obtaining healthcare was associated with maternal morbidity ( $\mathrm{P}$ value $=0.005)$ with women who do not have any say in taking decisions regarding obtaining healthcare experiencing more maternal morbidity than women who take decisions regarding obtaining healthcare themselves (OR: $2.35 ; 95 \%$ CI 1.29-4.30). This could be due to the fact that women who have no say in taking decisions regarding obtaining healthcare seek healthcare late and thus have more morbidity. These women also had less access to food intake during the antenatal period which explains their higher morbidity. It is also true that these women who have no say in taking decisions regarding obtaining healthcare had more of unwanted pregnancies which can also increase the maternal morbidity in them.

There was an association found between access to pocket money and maternal morbidity ( $\mathrm{P}$ value $=0.001$ ) with women having more pocket 
money experiencing more maternal morbidity than those women who lack pocket money (OR: $2.82 ; 95 \%$ CI 1.58-5.04). There was no association found between having pocket money and decision taking regarding obtaining healthcare. Ironically, unwanted pregnancies were more in women who had access to pocket money and these women also had their amount of physical activity unchanged or increased during the antenatal period. With only $9 \%$ of the population employed but $53.5 \%$ having access to pocket money, it can be concluded that the pocket money came from the earnings of their spouses but it did not necessarily mean that women with more access to pocket money will have more autonomy.

Maternal morbidity was also strongly associated with the type of past deliveries ( $\mathrm{P}$ value $=0.000$ ). Women who had past history of cesarean section all experienced a repeat cesarean section or underwent normal delivery with interventions. There is also a probability that these women also have poor general health status and thus experience more morbidity. There was an association between type of last delivery and maternal morbidity ( $\mathrm{P}$ value $=0.002$ ) as well with women delivering by cesarean section or normal delivery with interventions like episiotomy or forceps having much higher maternal morbidity than others (OR:2.66; 95\% CI 1.46-4.84).

The wantedness status of the index pregnancy was found to be associated with maternal morbidity ( $P$ value $=0.000)$ with those in whom the pregnancy is not wanted reporting higher morbidity than those in whom the pregnancy is wanted (OR: $3.69 ; 95 \%$ CI 2.05-6.63). This could be explained from the fact that as these women did not want the pregnancy they were reluctant to take care of their own health which could have resulted in more morbidity. It could also be that as these women did not want the pregnancy, the perceived morbidity (self-reported morbidity) was high in them.

Food intake during the antenatal period was associated with maternal morbidity (P value $=0.002$ ) with women in whom food intake during the antenatal period reduced experiencing more morbidity than those women in whom the food intake during the antenatal period increased or remained unchanged (OR: 2.52; 95\% CI 1.404.54). Physical activity was also associated with more of maternal morbidity ( $\mathrm{P}$ value $=0.000$ ) with women in whom physical activity increased or remained unchanged experiencing more morbidity than those women in whom the physical activity reduced (OR: 3.13; 95\% CI 1.74-5.63).

Awareness about the danger signs of pregnancy was found to be associated with maternal morbidity $(\mathrm{P}$ value $=0.000)$ with those aware of the danger signs of pregnancy experiencing more morbidity than those who are ignorant about it (OR: 4.88; 95\% CI 1.98-12.05). It is quite obvious that these women who are more aware of the danger signs of pregnancy will have more of perceived (self-reported) morbidity. As has been mentioned earlier, these women could have more of past history of ailments and poor general health status which could result in more morbidity.

Perceived availability of medicines in the health facility was found to be associated with maternal morbidity ( $\mathrm{P}$ value $=0.019)$ with non availability of medicines being associated with more maternal morbidity (OR: 3.09 ; 95\% CI 1.17-8.14). The non availability of medicines at the health facility during delivery was associated with more of postpartum morbidity ( $\mathrm{P}$ value $=0.027$ ). Behavior of the staff at the health facility was also found to be associated with maternal morbidity ( $P$ value $=0.046$ ) with bad behavior of the health facility staff associated with more maternal morbidity (OR: 2.32; 95\% CI 1.04-5.20). Though there was no association between bad behavior of the staff at the health facility and postpartum morbidity per se, there was an association between bad behavior of the staff at the health facility and post partum healthcare seeking ( $\mathrm{P}$ value $=0.047$ ). It could thus be that women who were treated badly by the staff at the healthcare facility during delivery did not seek healthcare at 
the health facility in the postnatal period and so experienced more maternal morbidity.

\section{Multivariate analysis using logistic regression}

In the preliminary analysis it was seen that some of the variables were strongly associated with maternal morbidity. The dependent variable considered here was discrete, categorical, with women as having either experienced maternal morbidity or not having experienced it. Therefore binary logistic regression was the obvious choice for multivariate analysis. However, for deciding on a multivariate model, all of the variables found to have significant association with maternal morbidity cannot be used because the number of classifications that would be then formed would be very high so as to render the analysis invalid. This analysis to develop a restricted model was undertaken using a series of chi-squares across various intermediate variables known to be associated. The various chi-squares describing the associations are included in [Table 6].

Socio-economic factors including religion was found to be associated with woman's autonomy measured by decision making power regarding obtaining own healthcare and access to pocket money. Socio-economic factors like religion and occupation were directly associated with maternal morbidity and inturn were themselves associated (SLI with occupation, SLI with education, education with occupation). Socio-economic status was also associated with food intake during the antenatal period (SLI, religion and food intake) and physical activity during antenatal period (occupation, education, religion with physical activity). Given that socio-economic status strongly determines women's autonomy, food intake and physical activity during the antenatal period, in the final analysis these variables (women's autonomy, food intake and physical activity in the antenatal period) that are more proximate determinants of maternal morbidity were considered.

Among women's autonomy variables, decision making power regarding obtaining healthcare and pocket money were strongly associated with maternal morbidity and no association was found between these two. However, decision making power regarding obtaining healthcare and pocket money had a strong association with food intake and physical activity during the antenatal period and also awareness of the danger signs. Thus food intake and physical activity during the antenatal period and also awareness of danger signs are shaped by the women's socio-economic status and autonomy. For further analysis of maternal morbidity, it was therefore possible to consider food intake and physical activity during antenatal period and awareness of danger signs as proxies for women's autonomy.

The past history of ailments was associated with awareness of danger signs and wantedness of the last pregnancy. It is possible that the past history of ailments gave rise to a better understanding of the danger signs of pregnancy. Further, the wantedness of the last pregnancy ie whether a woman chose to become pregnant with the last pregnancy or not is related somewhat to her physical well being. Therefore, we eliminated both past history of ailments and wantedness of the last pregnancy from the analysis with respect to maternal morbidity. Thus awareness of danger signs was taken as a proxy for the past history of ailments and wantedness of the last pregnancy.

Many of the proximate determinants were strongly associated with the type of last delivery and some with the type of past delivery. But type of last delivery is strongly determined by type of past delivery. Therefore food intake and physical activity during antenatal period, awareness of danger signs and type of last delivery were retained for the final analysis as in [Table 7].

The proportion of cases correctly predicted by the model is $76.4 \%$.

From this model it is evident that food intake during antenatal period is associated with maternal morbidity $(\mathrm{P}$ value $=0.007)$ with women in whom food intake during the antenatal period reduced experiencing more morbidity than those women in whom the food intake during the 
antenatal period increased or remained unchanged (OR: 2.42; 95\% CI 1.27-4.58). Physical activity during the antenatal period is also associated with more of maternal morbidity $(\mathrm{P}$ value $=0.001)$ with women in whom physical activity increased or remained unchanged experiencing more morbidity than those women in whom the physical activity reduced (OR: 3.01; 95\% CI 1.72-6.74).

Awareness about the danger signs of pregnancy was found to be associated with maternal morbidity $(\mathrm{P}$ value $=0.011)$ with those aware of the danger signs of pregnancy experiencing more morbidity than those who were ignorant about it (OR:3.42; 95\% CI 1.35-8.82). The association between type of last delivery by cesarean section or normal delivery with interventions like episiotomy or forceps having much higher maternal morbidity than others (OR: $2.55 ; 95 \%$ CI 1.33-4.89).
Table 1: Socio-economic profile of the study population

\begin{tabular}{|c|c|}
\hline \multicolumn{2}{|l|}{ Religion } \\
\hline Muslims & $57.5 \%$ \\
\hline Hindus & $42.5 \%$ \\
\hline \multicolumn{2}{|l|}{ Education of the Women } \\
\hline No formal education & $50.5 \%$ \\
\hline $1-5$ years of schooling & $24.0 \%$ \\
\hline $6-10$ years of schooling & $23.0 \%$ \\
\hline $10+2$ level & $1.5 \%$ \\
\hline Graduation complete & $1.0 \%$ \\
\hline \multicolumn{2}{|l|}{ Occupation of the Women } \\
\hline Housewife & $91.0 \%$ \\
\hline Employed & $9.0 \%$ \\
\hline \multicolumn{2}{|l|}{ Marital Status of the Women } \\
\hline Married and stays with Husband & $95.5 \%$ \\
\hline Married but separated & $1.0 \%$ \\
\hline Married but deserted & $2.5 \%$ \\
\hline Married but husband works elsewhere & $1.0 \%$ \\
\hline \multicolumn{2}{|l|}{ Education of the Husband } \\
\hline No formal education & $38.3 \%$ \\
\hline $1-5$ years of schooling & $27.5 \%$ \\
\hline $6-10$ years of schooling & $28.5 \%$ \\
\hline $10+2$ level & $5.2 \%$ \\
\hline Graduation complete & $0.5 \%$ \\
\hline \multicolumn{2}{|l|}{ SLI(Standard of Living Index) } \\
\hline Low & $38.0 \%$ \\
\hline Medium & $56.5 \%$ \\
\hline High & $5.5 \%$ \\
\hline \multicolumn{2}{|l|}{ Ailments prior to last pregnancy } \\
\hline No ailments & $85.0 \%$ \\
\hline Hypertension & $3.0 \%$ \\
\hline Anemia & $0.5 \%$ \\
\hline Asthma & $1.5 \%$ \\
\hline Tuberculosis & $3.5 \%$ \\
\hline Malaria & $2.5 \%$ \\
\hline Jaundice & $2.5 \%$ \\
\hline Others & $1.5 \%$ \\
\hline \multicolumn{2}{|c|}{$\begin{array}{l}\text { Healthcare seeking by the woman for the past } \\
\text { ailments ( } 15 \% \text { or } 30 \text { women had past history of } \\
\text { ailments }\end{array}$} \\
\hline \multicolumn{2}{|l|}{ Yes } \\
\hline \multirow[t]{2}{*}{ No } & $76.7 \%$ \\
\hline & $23.3 \%$ \\
\hline
\end{tabular}


Table 2: Autonomy and decision making power of the study population

\begin{tabular}{|l|c|}
\hline & Decision regarding obtaining healthcare \\
\hline Herself & $34 \%$ \\
\hline Herself with someone & $2.5 \%$ \\
\hline Others & $63.5 \%$ \\
\hline Yes & Access to pocket money \\
\hline No & $53.5 \%$ \\
\hline & $46.5 \%$ \\
\hline Yes & Beaten or mistreated physically \\
\hline No & $28.5 \%$ \\
\hline Not willing to answer & $68.0 \%$ \\
\hline & $3.5 \%$ \\
\hline Husband & $89.5 \%$ \\
\hline Husband, Mother-in-law, Sister-in-law & $3.5 \%$ \\
\hline Mother & $7.0 \%$ \\
\hline & Beaten by whom (57 cases gave history of being beaten) \\
\hline A few times & $77.2 \%$ \\
\hline Many times & $22.8 \%$ \\
\hline
\end{tabular}

Table 3: Distribution of the Pregnancy history of the study population

\begin{tabular}{|l|c|}
\hline & Past Pregnancy outcomes \\
\hline Not applicable & $38.0 \%$ \\
\hline Live birth & $49.5 \%$ \\
\hline Abortion or Still Birth & $11.5 \%$ \\
\hline Abortion and Still Birth & $1.0 \%$ \\
\hline & Past modes of Delivery \\
\hline Not applicable & \\
\hline Normal delivery & \\
\hline Caesarean & \\
\hline & No. of pregnancies experienced to date \\
\hline 1-2 pregnancies & $72.5 \%$ \\
\hline 3- 4 pregnancies & $20.5 \%$ \\
\hline 4-7 pregnancies & $7.0 \%$ \\
\hline & Place of last (index) delivery \\
\hline Home & $6.6 \%$ \\
\hline Private Nursing home & $4.0 \%$ \\
\hline Government hospital & $7.1 \%$ \\
\hline MGM Medical College and LSK Hospital & $82.3 \%$ \\
\hline & Person attending the last (index) delivery \\
\hline Dai & $6.6 \%$ \\
\hline Doctor & $81.8 \%$ \\
\hline Doctor, Nurse & $5.0 \%$ \\
\hline Nurse & $6.6 \%$ \\
\hline
\end{tabular}


Table 4: Antenatal profile and availability of maternal healthcare services of the study population

\begin{tabular}{|c|c|}
\hline & Wantedness status of the last (index) pregnancy \\
\hline Yes & $54.5 \%$ \\
\hline \multirow[t]{2}{*}{ No } & $45.5 \%$ \\
\hline & Amount of Physical Activity during Antenatal Period \\
\hline Amount reduced & $45.5 \%$ \\
\hline Amount remained unchanged & $48.0 \%$ \\
\hline \multirow[t]{2}{*}{ Amount increased } & $6.5 \%$ \\
\hline & Awareness of Danger Signs \\
\hline Yes & $14.5 \%$ \\
\hline \multirow[t]{2}{*}{ No } & $85.5 \%$ \\
\hline & Healthworker's visit in the antenatal period \\
\hline Yes & $94.5 \%$ \\
\hline \multirow[t]{2}{*}{ No } & $5.5 \%$ \\
\hline & Frequency of visit in the Antenatal period \\
\hline Once in every week & $18.5 \%$ \\
\hline Once in every two weeks & $37.0 \%$ \\
\hline Once in every month & $39.0 \%$ \\
\hline \multirow[t]{2}{*}{ No } & $5.5 \%$ \\
\hline & Healthcare worker's visit in the postnatal period \\
\hline Yes & $96.5 \%$ \\
\hline \multirow[t]{2}{*}{ No } & $3.5 \%$ \\
\hline & Frequency of visit in the postnatal period \\
\hline Once in every week & $18.0 \%$ \\
\hline Once in every two weeks & $40.5 \%$ \\
\hline Once in every month & $38.0 \%$ \\
\hline \multirow[t]{2}{*}{ No } & $3.5 \%$ \\
\hline & Distance of the nearest health facility from the women's home \\
\hline$<1 \mathrm{Km}$ & $65.5 \%$ \\
\hline $1-<2 \mathrm{Kms}$ & $28.5 \%$ \\
\hline $2-5 \mathrm{Kms}$ & $3.5 \%$ \\
\hline \multirow[t]{2}{*}{$>5 \mathrm{Kms}$} & $2.5 \%$ \\
\hline & Nature of Services in the Nearest Health Facility \\
\hline Doctor, private, qualified & $7.5 \%$ \\
\hline Doctor, private, unqualified & $2.5 \%$ \\
\hline $\begin{array}{l}\text { MGM Medical College \& Hospital } \\
\text { Doctor and Health worker }\end{array}$ & $84.5 \%$ \\
\hline \multirow[t]{2}{*}{ Government Hospital } & $5.5 \%$ \\
\hline & $\begin{array}{c}\begin{array}{c}\text { Waiting time at the health facility (if woman experienced hospitalization } \\
\text { during last delivery) }\end{array} \\
\end{array}$ \\
\hline$<15$ mins & $77.5 \%$ \\
\hline 15 mins $-<1 / 2 \mathrm{hrs}$ & $20.9 \%$ \\
\hline \multirow[t]{2}{*}{$1 / 2 \mathrm{hrs}$ and more } & $1.6 \%$ \\
\hline & $\begin{array}{c}\text { Problems faced in seeking healthcare (if the woman experienced } \\
\text { hospitalization during the last delivery) }\end{array}$ \\
\hline Yes & $10.7 \%$ \\
\hline \multirow[t]{2}{*}{ No } & $89.3 \%$ \\
\hline & $\begin{array}{c}\text { Perceived availability of medicines in the health facility (if the woman } \\
\text { experienced hospitalization during the last delivery) }\end{array}$ \\
\hline Yes & $13.4 \%$ \\
\hline \multirow[t]{2}{*}{ No } & $86.6 \%$ \\
\hline & $\begin{array}{c}\text { Behavior of staff at the Health Facility (if woman experienced } \\
\text { hospitalization during the last delivery) }\end{array}$ \\
\hline Good & $84 \%$ \\
\hline \multirow[t]{2}{*}{ Bad } & $16 \%$ \\
\hline & $\begin{array}{c}\text { Satisfaction with overall care at health facility (if woman experienced } \\
\text { hospitalization during the last delivery) }\end{array}$ \\
\hline Yes & $94.1 \%$ \\
\hline No & $5.9 \%$ \\
\hline
\end{tabular}


Table 5: Correlates of maternal morbidity in the study population

\begin{tabular}{|c|c|c|c|c|c|}
\hline Correlates & & $\begin{array}{c}\text { Overall } \\
\text { Maternal } \\
\text { Morbidity }\end{array}$ & & Total & $\begin{array}{l}X 2(p \\
\text { value })\end{array}$ \\
\hline & & Yes & No & & \\
\hline \multirow[t]{2}{*}{ Religion } & Muslims & 67 & 48 & 115 & \\
\hline & Hindus & 22 & 63 & 85 & 0.000 \\
\hline Total & & 89 & 111 & 200 & \\
\hline \multirow[t]{4}{*}{ Age Group } & $15-19$ yrs & 17 & 30 & 47 & \\
\hline & $20-24$ yrs & 38 & 49 & 87 & \\
\hline & $25-29$ yrs & 22 & 28 & 50 & \\
\hline & $30 \mathrm{yrs}$ and above & 12 & 4 & 16 & 0.061 \\
\hline Total & & 89 & 111 & 200 & \\
\hline \multirow{2}{*}{ Education of the woman } & Yes & 44 & 55 & 99 & \\
\hline & No & 45 & 56 & 101 & 1.000 \\
\hline Total & & 89 & 111 & 200 & \\
\hline \multirow[t]{2}{*}{ Occupation of the woman } & Yes & 13 & 5 & 18 & \\
\hline & No & 76 & 106 & 182 & 0.023 \\
\hline Total & & 89 & 111 & 200 & \\
\hline \multirow[t]{2}{*}{ Marital status } & $\begin{array}{l}\text { Married and stays with } \\
\text { husband }\end{array}$ & 84 & 107 & 191 & \\
\hline & $\begin{array}{c}\text { Separated/Deserted/Husband } \\
\text { works elsewhere }\end{array}$ & 5 & 4 & 9 & 0.515 \\
\hline Total & & 89 & 111 & 200 & \\
\hline \multirow[t]{2}{*}{ Education of Husband } & Yes & 47 & 72 & 119 & \\
\hline & No & 38 & 36 & 74 & 0.136 \\
\hline Total & & 85 & 108 & 193 & \\
\hline \multirow[t]{2}{*}{ Age of first pregnancy } & $<21 \mathrm{yrs}$ & 64 & 89 & 153 & \\
\hline & $21 \mathrm{yrs}$ and above & 25 & 22 & 47 & 0.183 \\
\hline Total & & 89 & 111 & 200 & \\
\hline \multirow[t]{2}{*}{ Past History of ailments } & Yes & 23 & 7 & 30 & \\
\hline & No & 66 & 104 & 170 & 0.000 \\
\hline Total & & 89 & 111 & 200 & \\
\hline \multirow[t]{2}{*}{ SLI } & Low & 31 & 45 & 76 & \\
\hline & Medium and High & 58 & 66 & 124 & 0.382 \\
\hline Total & & 89 & 111 & & \\
\hline \multirow[t]{2}{*}{$\begin{array}{l}\text { Decision taking regarding } \\
\text { own healthcare }\end{array}$} & Woman herself involved & 23 & $\mathbf{5 0}$ & 73 & \\
\hline & Others totally & 66 & 61 & 127 & 0.005 \\
\hline Total & & 89 & 111 & 200 & \\
\hline \multirow[t]{2}{*}{ Access to pocket money } & Yes & 60 & 47 & 107 & \\
\hline & No & 29 & 64 & 93 & 0.001 \\
\hline Total & & 89 & 111 & 200 & \\
\hline
\end{tabular}




\begin{tabular}{|c|c|c|c|c|c|}
\hline \multirow[t]{2}{*}{$\begin{array}{l}\text { Beaten or physically } \\
\text { mistreated in the last } 1 \text { year }\end{array}$} & Yes & 29 & 28 & 57 & \\
\hline & No & 56 & 80 & & \\
\hline \multirow[t]{2}{*}{ Total } & & & & 136 & 0.266 \\
\hline & & 85 & 108 & 193 & \\
\hline \multirow[t]{2}{*}{$\begin{array}{l}\text { Outcome of past pregnancies } \\
\text { (History of } \\
\text { abortion/stillbirth) }\end{array}$} & Yes & 14 & 11 & 25 & \\
\hline & No & 44 & 55 & 99 & 0.371 \\
\hline Total & & 58 & 66 & 124 & \\
\hline \multirow[t]{2}{*}{$\begin{array}{llll}\begin{array}{l}\text { Type of } \\
\text { (History } \\
\text { section) }\end{array} & \begin{array}{c}\text { past } \\
\text { of }\end{array} & \begin{array}{l}\text { deliveries } \\
\text { Cesarean }\end{array} \\
\end{array}$} & Yes & 20 & $\mathbf{0}$ & 20 & \\
\hline & No & 36 & 63 & 99 & 0.000 \\
\hline Total & & 56 & 63 & 119 & \\
\hline \multirow[t]{2}{*}{$\begin{array}{l}\text { No. of pregnancies } \\
\text { experienced to date }\end{array}$} & 1 and 3 or more & 61 & 70 & 131 & \\
\hline & 2 & 28 & 41 & 69 & 0.456 \\
\hline Total & & 89 & 111 & 200 & \\
\hline \multirow[t]{2}{*}{$\begin{array}{l}\text { Spacing between the last } \\
\text { pregnancy and the pregnancy } \\
\text { before that }\end{array}$} & $<2 \mathrm{yrs}$ & 18 & 12 & 30 & \\
\hline & 2 yrs and above & 40 & 54 & 94 & 0.141 \\
\hline Total & & 58 & 66 & 124 & \\
\hline \multirow[t]{2}{*}{ Type of last delivery } & $\begin{array}{l}\text { Cesarean/normal with } \\
\text { interventions }\end{array}$ & 63 & 56 & 119 & \\
\hline & Normal without interventions & 24 & 55 & 79 & 0.002 \\
\hline Total & & 87 & 111 & 198 & \\
\hline \multirow[t]{2}{*}{ Place of last delivery } & Home & 3 & 10 & 13 & \\
\hline & $\begin{array}{c}\text { Nursing home,Government } \\
\text { hospital, MGM Medical } \\
\text { College }\end{array}$ & 84 & 101 & 185 & 0.152 \\
\hline Total & & 87 & 111 & 198 & \\
\hline \multirow[t]{3}{*}{$\begin{array}{l}\text { Person who attended the } \\
\text { dleivery (Skilled attendant) }\end{array}$} & Yes & 84 & 101 & 185 & \\
\hline & No & 3 & 10 & 13 & 0.152 \\
\hline & & 87 & 111 & 109 & \\
\hline \multirow[t]{3}{*}{$\begin{array}{l}\begin{array}{l}\text { Wantedness } \\
\text { pregnancy }\end{array} \\
\end{array}$} & Yes & 33 & 76 & 109 & \\
\hline & No & 56 & 35 & 91 & 0.000 \\
\hline & & 89 & 111 & 200 & \\
\hline
\end{tabular}




\begin{tabular}{|c|c|c|c|c|c|}
\hline $\begin{array}{l}\text { Amount of food intake } \\
\text { during antenatal period }\end{array}$ & $\begin{array}{c}\text { Amount } \\
\text { increased/Unchanged }\end{array}$ & 45 & 80 & 125 & \\
\hline & Amount reduced & 44 & 31 & 75 & 0.002 \\
\hline & & 89 & 111 & 200 & \\
\hline $\begin{array}{l}\text { Amount of physical activity } \\
\text { during antenatal period }\end{array}$ & Amount reduced & 27 & 64 & 91 & \\
\hline & $\begin{array}{c}\text { Amount remained } \\
\text { unchanged/increased }\end{array}$ & 62 & 47 & 109 & 0.000 \\
\hline Total & & 89 & 111 & 200 & \\
\hline $\begin{array}{l}\text { Awareness about danger } \\
\text { signs }\end{array}$ & Yes & 22 & 7 & 29 & \\
\hline & No & 67 & 104 & 171 & 0.000 \\
\hline Total & & 89 & 111 & 200 & \\
\hline $\begin{array}{l}\text { Healthworker's visit in the } \\
\text { antenatal period }\end{array}$ & Yes & 84 & 105 & 189 & \\
\hline & No & 5 & 6 & 11 & 1.000 \\
\hline Total & & 89 & 111 & 200 & \\
\hline Nearest Health Facility & $<2 \mathrm{kms}$ & 87 & 101 & 188 & \\
\hline & $2 \mathrm{Kms}$ and above & 2 & 10 & 12 & 0.069 \\
\hline Total & & 89 & 111 & 200 & \\
\hline $\begin{array}{l}\text { Healthworker's visit in the } \\
\text { postnatal period }\end{array}$ & Yes & 85 & 108 & 193 & \\
\hline & No & 4 & 3 & 7 & 0.702 \\
\hline Total & & 89 & 111 & 200 & \\
\hline $\begin{array}{l}\text { Waiting time at the health } \\
\text { facility }\end{array}$ & $<15$ mins & 70 & 75 & 145 & \\
\hline & 15 mins and above & 16 & 26 & 42 & 0.293 \\
\hline Total & & 86 & 101 & 187 & \\
\hline $\begin{array}{l}\text { Problems faced in getting } \\
\text { care }\end{array}$ & Yes & 11 & 9 & 20 & \\
\hline & No & 75 & 92 & 167 & 0.479 \\
\hline Total & & 86 & 101 & 187 & \\
\hline $\begin{array}{l}\text { Reported availability of } \\
\text { medicines at the Health } \\
\text { facility }\end{array}$ & Yes & 6 & 19 & 25 & \\
\hline & No & 80 & 82 & 162 & 0.019 \\
\hline Total & & 86 & 101 & 187 & \\
\hline Behaviour of the staff & Good & 67 & 90 & 157 & \\
\hline & Bad & 19 & 11 & 30 & 0.046 \\
\hline Total & & 86 & 101 & 187 & \\
\hline $\begin{array}{l}\begin{array}{l}\text { Satisfaction with } \\
\text { healthcare }\end{array} \\
\text { overall }\end{array}$ & Yes & 81 & 95 & 176 & \\
\hline & No & 5 & 6 & 11 & 1.000 \\
\hline Total & & 86 & 101 & 187 & \\
\hline
\end{tabular}


Table 6: Calculations of associations for deciding on the Multivariate Model

\begin{tabular}{|c|c|c|c|}
\hline Determinants & Determinants & X2 value & p-value \\
\hline \multirow[t]{8}{*}{$\begin{array}{lr}\begin{array}{l}\text { Decision } \\
\text { regarding }\end{array} & \begin{array}{r}\text { making } \\
\text { obtaining }\end{array} \\
\end{array}$} & Religion & 0.093 & 0.769 \\
\hline & Education of the woman & 0.848 & 0.381 \\
\hline & Occupation of the woman & 14.541 & 0.000 \\
\hline & Past history of ailments & 1.472 & 0.304 \\
\hline & SLI & 0.111 & 0.765 \\
\hline & Amount of food intake during antenatal period & 5.894 & 0.052 \\
\hline & Amount of physical activity during anetnatal period & 9.813 & 0.007 \\
\hline & Wantedness status of the last pregnancy & 9.078 & 0.003 \\
\hline \multirow[t]{8}{*}{$\begin{array}{lll}\text { Access } & \text { to } & \text { pocket } \\
\text { money } & & \\
\end{array}$} & Religion & 7.384 & 0.010 \\
\hline & Education of the woman & 0.075 & 0.887 \\
\hline & Occupation of the woman & 9.958 & 0.002 \\
\hline & Past history of ailments & 0.142 & 0.843 \\
\hline & SLI & 1.96 & 0.190 \\
\hline & Amount of food intake during antenatal period & 2.223 & 0.329 \\
\hline & Amount of physical activity during anetnatal period & 185.244 & 0.000 \\
\hline & Wantedness status of the last pregnancy & 5.604 & 0.023 \\
\hline $\begin{array}{lr}\begin{array}{l}\text { Decision } \\
\text { regarding } \\
\text { healthcare }\end{array} & \begin{array}{r}\text { making } \\
\text { obtaining }\end{array} \\
\end{array}$ & Access to pocket money & 0.077 & 0.883 \\
\hline SLI & Education of the woman & 16.831 & 0.000 \\
\hline SLI & Occupation of the woman & 6.628 & 0.020 \\
\hline $\begin{array}{l}\text { Education of the } \\
\text { woman }\end{array}$ & Occupation of the woman & 8.530 & 0.005 \\
\hline \multirow[t]{5}{*}{$\begin{array}{l}\text { Amount of food intake } \\
\text { during antenatal } \\
\text { period }\end{array}$} & Religion & 6.876 & 0.012 \\
\hline & Education of the woman & 0.108 & 0.772 \\
\hline & Occupation of the woman & 1.319 & 0.309 \\
\hline & Past history of ailments & 2.353 & 0.153 \\
\hline & SLI & 3.380 & 0.073 \\
\hline \multirow[t]{5}{*}{$\begin{array}{l}\text { Amount of } \begin{array}{r}\text { physical } \\
\text { activity }\end{array} \\
\text { antenatal period }\end{array}$} & Religion & 9.255 & 0.010 \\
\hline & Education of the woman & 6.477 & 0.039 \\
\hline & Occupation of the woman & 141.119 & 0.000 \\
\hline & Past history of ailments & 0.431 & 0.556 \\
\hline & SLI & 3.717 & 0.156 \\
\hline \multirow[t]{6}{*}{$\begin{array}{l}\text { Awareness of danger } \\
\text { signs }\end{array}$} & Religion & 14.351 & 0.000 \\
\hline & Education of the woman & 8.728 & 0.004 \\
\hline & Occupation of the woman & 88.290 & 0.000 \\
\hline & Past history of ailments & 0.574 & 0.537 \\
\hline & SLI & 10.098 & 0.004 \\
\hline & $\begin{array}{c}\text { Decision making power regarding obtaining own } \\
\text { healthcare }\end{array}$ & 7.161 & 0.008 \\
\hline
\end{tabular}




\begin{tabular}{|c|c|c|c|}
\hline & Access to pocket money & 5.477 & 0.041 \\
\hline & Type of past delivery & 10.350 & 0.004 \\
\hline & Type of last delivery & 5.591 & 0.061 \\
\hline \multirow[t]{6}{*}{$\begin{array}{ll}\text { Past history of } \\
\text { ailments }\end{array}$} & Religion & 1.214 & 0.320 \\
\hline & Education of the woman & 3.690 & 0.740 \\
\hline & Occupation of the woman & 0.430 & 0.738 \\
\hline & SLI & 0.500 & 1.000 \\
\hline & Wantedness status of the last pregnancy & 4.526 & 0.046 \\
\hline & Type of last delivery & 2.426 & 0.297 \\
\hline \multirow[t]{11}{*}{ Type of past delivery } & Type of last delivery & 66.709 & 0.000 \\
\hline & Religion & 0.081 & 1.000 \\
\hline & Education of the woman & 0.014 & 1.000 \\
\hline & Occupation of the woman & 6.003 & $\mathbf{0 . 0 2 0}$ \\
\hline & SLI & 0.134 & 0.807 \\
\hline & Past history of ailments & 0.092 & 0.752 \\
\hline & $\begin{array}{l}\text { Decision making power regarding obtaining own } \\
\text { healthcare }\end{array}$ & 0.933 & 0.454 \\
\hline & Access to pocket money & 1.623 & 0.226 \\
\hline & Wantedness status of the last pregnancy & 2.294 & 0.147 \\
\hline & Amount of food intake during antenatal period & 1.268 & 0.530 \\
\hline & Amount of physical activity during antenatal period & 9.686 & $\mathbf{0 . 0 0 8}$ \\
\hline \multirow[t]{10}{*}{ Type of last delivery } & Religion & 0.402 & 0.818 \\
\hline & Education of the woman & 4.113 & 0.115 \\
\hline & Occupation of the woman & 4.123 & 0.116 \\
\hline & SLI & 1.517 & 0.468 \\
\hline & Past history of ailments & 2.426 & 0.297 \\
\hline & $\begin{array}{l}\text { Decision making power regarding obtaining own } \\
\text { healthcare }\end{array}$ & 4.844 & 0.089 \\
\hline & Access to pocket money & 8.000 & 0.018 \\
\hline & Wantedness status of the last pregnancy & 9.164 & $\mathbf{0 . 0 1 0}$ \\
\hline & Amount of food intake during antenatal period & 9.512 & $\mathbf{0 . 0 5 0}$ \\
\hline & Amount of physical activity during anetnatal period & $\mathbf{1 1 . 2 1 4}$ & $\mathbf{0 . 0 2 4}$ \\
\hline \multirow[t]{8}{*}{$\begin{array}{l}\text { Behaviour of staff at } \\
\text { health facility }\end{array}$} & SLI & 1.938 & 0.281 \\
\hline & Religion & 8.255 & 0.005 \\
\hline & Education of the woman & 4.099 & 0.048 \\
\hline & Occupation of the woman & 0.006 & 1.000 \\
\hline & Type of last delivery & 0.818 & 0.516 \\
\hline & Type of past delivery & 0.439 & 0.541 \\
\hline & Past history of ailments & 2.288 & 0.155 \\
\hline & Healthcare seeking in the postpartum period & 13.347 & $\mathbf{0 . 0 3 8}$ \\
\hline \multirow[t]{8}{*}{$\begin{array}{l}\text { Perceived availability } \\
\text { of medicines }\end{array}$} & 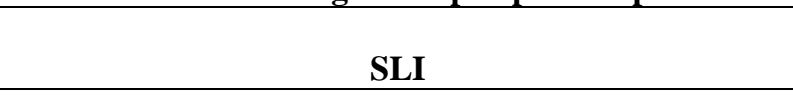 & 5.948 & 0.025 \\
\hline & Religion & 0.174 & 0.829 \\
\hline & Education of the woman & 7.965 & $\mathbf{0 . 0 0 5}$ \\
\hline & Occupation of the woman & 0.088 & 1.000 \\
\hline & Type of last delivery & 4.325 & $\mathbf{0 . 0 3 8}$ \\
\hline & Type of past delivery & 10.413 & 0.003 \\
\hline & Postpartum morbidity & 4.945 & $\mathbf{0 . 0 2 7}$ \\
\hline & Past history of ailments & 4.870 & 0.028 \\
\hline
\end{tabular}


Table 7: Multivariate analysis of self-reported maternal morbidity by food intake, physical activity during antenatal period, awareness of danger signs and type of last delivery

\begin{tabular}{|l|c|c|c|c|}
\hline Determinants & B & p value & OR & 95\% CI for OR \\
\hline Food intake during antenatal period* & 0.882 & 0.007 & 2.42 & $1.27-4.58$ \\
\hline Physical activity during antenata period** & 1.103 & 0.001 & 3.01 & $1.72-6.47$ \\
\hline Awareness of danger signs*** & 1.23 & 0.011 & 3.42 & $1.33-8.82$ \\
\hline Type of last delivery**** & 0.953 & 0.005 & 2.55 & $1.33-4.89$ \\
\hline
\end{tabular}

*Taking food intake reduced during antenatal period as reference category.

**Taking physical activity unchanged or increased during antenatal period as reference category.

***Taking awareness of danger signs present as reference category.

****Taking Cesarean sections/normal delivery but with interventions as reference category.

\section{Discussions}

\section{Prevalence of Maternal Morbidity}

The burden of maternal morbidity was high. Some of the Indian studies found maternal morbidity rates higher than this study. This could be due to the fact that a medical college was providing a basket of maternal healthcare services in this community, it could also be that as the levels of awareness and education among the women were poor, the self reported maternal morbidity was low.

Though the prevalence of the complaints varied among the studies in many instances, complaints during the antenatal, during labour and during the post partum period reported by the women in this study were quite similar as reported in other studies.

\section{Healthcare seeking behavior}

The rates of healthcare utilization were quite high in this study which could be due to the access and proximity of this community to the medical college. It also brought out the fairly high rates of utilization of the private sector for seeking healthcare.

\section{Correlates of Maternal Morbidity}

The correlates of maternal morbidity as was evident from this study were in conformity with other studies. In this study, religion (Muslim); lack of decision making power regarding obtaining healthcare; past history of ailments; past history of Cesarean sections; deliveries by Cesarean section or normal deliveries with interventions like episiotomies or forceps; reduced food intake and increased physical activity during antenatal period; awareness about the danger signs of pregnancy and wantedness status of the index pregnancy was associated with maternal morbidity. Religion was related to the lack of decision making power regarding obtaining healthcare in a society where there is female subjugation by the men folk and other elders. Past history of ailments was associated with maternal morbidity. Whether the pregnancy was wanted or not, reduced food intake and manual labour into late pregnancy were associated with adverse maternal outcomes. Like the findings in this study, awareness about danger signs of pregnancy was also associated with more of reported maternal morbidity. However, unlike this study, women's decision making power regarding obtaining healthcare was found to be associated with more maternal morbidity.

The correlates of maternal morbidity as was evident from this study were in conformity with other studies. In addition the relatively low levels of autonomy and lack of knowledge about the physiological matters related to pregnancy result in higher levels of physical activities during pregnancy. Further, women's lack of awareness about the danger signs during pregnancy may also contribute to maternal morbidity.

While use of the healthcare services provided by the Medical College for antenatal care and delivery is high, yet for minor pregnancy related problems the use of private practitioners is resorted to. This is due to the easy availability of the private practitioners at all times. But the community trusts the health workers and the doctors of the Medical College and this opportunity can be used to improve their 
healthcare seeking and change beliefs that are detrimental to women's wellbeing.

This study did not find any association between the SLI and women's education and maternal morbidity. This could however be explained from the fact that there was not much variation in the Socio-economic status or education of the women as they all hailed from the same locality.

Physical violence during the last 1 year prior to delivery was found to be associated with adverse maternal outcomes in some studies. However, this was not revealed in our study. This could be due to the fact that this was a sensitive issue in the cultural context of the region, women refused to answer to this question and women who reported no physical violence in the last 1 year prior to delivery did not report correctly.

It is evident from the findings of the study that the causes of maternal morbidity are deeply entrenched in the sociocultural milieu. The findings bring out the socio-economic context in which the women suffer from maternal morbidity and stresses on the importance of self-reported community based studies on maternal morbidity to understand the social determinants of maternal morbidity more and thus come up with plausible solutions.

\section{Conclusions}

The burden of maternal morbidity is high particularly the post partum morbidity. In addition the relatively low levels of autonomy and lack of knowledge about the physiological matters related to pregnancy result in higher levels of physical activities during pregnancy. Further, women's lack of awareness about the danger signs during pregnancy may also contribute to maternal morbidity.

While use of the healthcare services provided by the Medical College for antenatal care and delivery is high, yet for minor pregnancy related problems the use of private practitioners is resorted to. This is due to the easy availability of the private practitioners at all times. But the community trusts the health workers and the doctors of the Medical College and this opportunity can be used to improve their healthcare seeking and change beliefs that are detrimental to women's wellbeing.

\section{Limitations}

The study was based on self reported maternal morbidity which relies on women's perceptions about maternal morbidity. Thus there is always a chance of over or underreporting of maternal morbidity.

The sample of this study was drawn from women who delivered within $1^{\text {st }}$ June 2018 to $31^{\text {st }}$ May 2019. As the data collection started from July 2018, the recall period for many participants was about a year leading to the chance of recall bias.

This is a cross sectional study, so that temporality of many associations that were significant could have been lost.

The study was undertaken in the community being served by the Medical College providing good access to maternal healthcare services. So, generalizability of the study in other areas is questionable.

Nevertheless, in the absence of any published data on maternal morbidity from the State, this study was an earnest endeavor by the study team to throw some light on the study topic and thus come up with recommendations aimed towards improving the health of the mothers.

\section{Conflict of Interest}

The authors declare there is no conflict of interest in doing the study.

\section{Acknowledgement}

We acknowledge the support extended by $\mathrm{Dr}$ Dilip Kumar Jaiswal, Director, MGM University and LSK Hospital, Kishanganj, Bihar for conducting the study.

\section{References}

1. Maternal mortality for 181 countries, 1980-2008: a systematic analysis of progress towards Millennium Development Goal 5. Hogan MC, 
Foreman KJ, Naghavi M, Ahn SY, Wang M, Makela SM, Lopez AD, Lozano R, Murray CJ Lancet. 2010 May 8; 375(9726):1609-23.

2. WHO, UNICEF, UNFPA et al. Trends in maternal mortality: 1990 to 2015. Geneva, Switzerland: Executive Summary; 2015.

3. WHO, UNICEF, UNFPA, et al. Trends in maternal mortality : 1990 to 2010. Geneva, Switzerland, 2012.

4. UN. The Sustainable Development Goals 2015 - 2030. 2018. [Last accessed on 2019 Nov 20]. Available from: https://unagp.org/the-sustainable-development-goals2015-2030/

5. Pregnancy-related mortality in the United States, 2006-2010. Creanga AA, Berg CJ, Syverson C, Seed K, Bruce FC, Callaghan WM Obstet Gynecol. 2015 Jan; 125(1):512.

6. Frequency of and factors associated with severe maternal morbidity. Grobman WA, Bailit JL, Rice MM, Wapner RJ, Reddy UM, Varner MW, Thorp JM Jr, Leveno KJ, Caritis SN, Iams JD, Tita AT, Saade G, Sorokin Y, Rouse DJ, Blackwell SC, Tolosa JE, Van Dorsten JP, Eunice Kennedy Shriver National Institute of Child Health and Human Development (NICHD) Maternal-Fetal Medicine Units (MFMU) Network. Obstet Gynecol. 2014 Apr; 123(4):804-10.

7. The prevalence of maternal near miss: a systematic review. Tunçalp O, Hindin MJ, Souza JP, Chou D, Say L BJOG. 2012 May; 119(6):653-61.

8. WHO (World Health Organization). 2010. ICD-10: International Classification of Diseases and Related Health Problems. 10th Revision, Vol. 2, Instruction Manual. Geneva: WHO.
9. An Examination of the Maternal Health Quality of Care Landscape in India. March 2, 2017 So O’Neil Katie NaeveRajaniVed. Last accessed on 20.11.2019. Url: https://www.macfound.org/media/files/502 68_Landscape_Report_2017.03.02.pdf

10. Mohapatra A, Gomare M. A critical appraisal of the maternal and child health scenario in a metropolitan city in India with reference to achievements of millennium development goals. J Family Med Prim Care 2019;8:995-1001.

11. Filippi V, Chou D, Ronsmans C, et al. Levels and Causes of Maternal Mortality and Morbidity. In: Black RE, Laxminarayan $\mathrm{R}$, Temmerman $\mathrm{M}$, et al., editors. Reproductive, Maternal, Newborn, and Child Health: Disease Control Priorities, Third Edition (Volume 2). Washington (DC): The International Bank for Reconstruction and Development / The World Bank; 2016 Apr 5. Chapter 3. Available from: https://www.ncbi.nlm.nih.gov/books/NBK 361917/ doi: 10.1596/978-1-4648-03482_ch3

12. McCauley M, Madaj B, White SA, et al Burden of physical, psychological and social ill-health during and after pregnancy among women in India, Pakistan, Kenya and Malawi. BMJ Global Health 2018;3:e000625. 